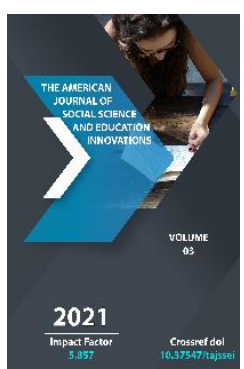

Copyright: Original content from this work may be used under the terms of the creative commons attributes 4.0 licence.

\section{Current Issues Of Training Professionals In Military Education In Humanitarian Universities}

Khasanov A.T.

(PhD), Head Of The Department Of Sports Games, Ferghana State University, Uzbekistan

Allomov E.I.

Teacher Of The Department Of Sports Games, Ferghana State University, Uzbekistan

\title{
ABSTRACT
}

The issues of introduction of pedagogical technologies in the educational process with a focus on professional-practical physical training in the training of specialists in pre-service military education in the faculties of military education of higher humanitarian educational institutions are studied.

\section{KEYWORDS}

Pedagogical technology, sociological research, innovation, military skills, concept, motivation, methodology, professional activity.

\section{INTRODUCTION}

By the beginning of the new century, the geopolitical situation in the world has changed radically. In particular, competition between different geopolitical forces has intensified, and the balance in the geopolitical arena has taken on a new dimension. In this regard, the issue of ensuring the security of the country is becoming a task of strategic importance. The realization of this socially important task depends on the introduction of young people to the basics of military education before conscription. To do this, first of all, it is necessary to reorganize the process of pre- 
service military education on the basis of modern pedagogical technologies.

The National Program of Personnel Training states that "the system of training and education is not linked to the requirements of the ongoing processes of reform and renewal in society" [1].

According to the results of monitoring carried out by specialists, the professional and pedagogical skills of a specialist in pre-service military education will improve only after 7-8 years of pedagogical activity in educational institutions. During this period, he fully masters the various components of vocational education, new innovative teaching technologies, modern methods and techniques that serve to enhance the content of education. But the formation of a specialist is not a process that happens spontaneously, of course. It must be managed and directed in accordance with the purpose. To do this, first of all, a pre-service military education teacher should be provided with a wide range of information about their field. Because only a specialist armed with theoretical and political knowledge in the field of military equipment, military doctrine and computer science will be able to effectively organize their professional activities, to show examples of creativity in various areas of professional activity.

Also, in order to form the professional and pedagogical skills of a specialist in pre-service military education, the main pedagogical tasks related to this process should be defined in detail. In our opinion, this category of tasks includes:

- Study the essence, laws and features of the pedagogical process;

- Development of an effective concept of educating students of specialized faculties, taking into account changes in society and in the Armed Forces;

- Development of training and educational processes, forecasting of future voluntary and psychological support of daily and combat activities;

- Substantiate the content, methodology and laws of student self-improvement and create conditions for its motivation and interest;

- Development of theory and practice of formation of pedagogical culture of the military education specialist before the next conscription.

The practical work of a pre-service military education specialist should be focused on learning best practices of practical work with young conscripts, mastering modern methods of training and education based on the theoretical foundations of pre-service military training, preparing young people for effective military service models, algorithms and technologies. If the professional and pedagogical activity of the teacher is organized on the basis of a combination of ideals, interests and material interests, then it is expedient to pay attention to the development of personal qualities of the teacher [2,3].

In the formation of professional and pedagogical skills of a specialist in preconscription military education should serve as a methodological basis "Regulations on the role of the will-psychological factor in the Armed Forces and the essence of education." Activity based on this methodological basis increases the level of psychological training of the specialist, allows to form the willpsychological, intellectual, physical and combat qualities, military skills necessary to achieve high combat readiness. 
Based on the requirements of modern pedagogical technology of training, it is recommended to include in the preconscription military education program additional sections consisting of physical training aimed at health, sports and health and practical movement. The introduction of new pedagogical technologies in the educational process helps to increase the pedagogical skills of pre-service military education teachers in solving pedagogical tasks by improving indepth professional knowledge, skills and abilities in various areas of pedagogical activity [4].

In order to determine the requirements for students in vocational training, to determine their knowledge in this area and ways to improve the physical training of future teachers of pre-service youth, an oral survey and a questionnaire survey were conducted among faculty and students of Fergana State University.

In the process of sociological research, 92 students from the faculty of pre-service military education participated in the analysis, which were divided equally among four stages of education (Table 1).

The survey revealed that the current system of vocational training of students can be improved by increasing the practical orientation of physical education.

Table 1

Students and professors of Fergana State University who took part in the survey.

\begin{tabular}{|c|c|c|c|c|}
\hline \multicolumn{5}{|c|}{ Controlled groups. } \\
\hline Course 1 & Course 2 & Course 3 & Course 4 & Teachers \\
\hline 24 & 24 & 23 & 21 & 26 \\
\hline
\end{tabular}

$72.3 \%$ of teachers and $61.3 \%$ of students surveyed acknowledged the importance of such training in sports.

Practice shows that students of the faculty of pre-service military education must master the laws of formation of theoretical and practical knowledge in the study of the subject "Professional and practical physical training" $[7,8]$.
The above considerations allow to determine the purpose of the research, that is, to provide in practice the justification of the program of vocational training of students of the Faculty of Pre-Conscription Military Education in humanitarian educational institutions.

The goal is achieved through the solution of general and special tasks, where the general tasks of vocational training derive from objective tasks and reflect the requirements 
for the professional activity and physical condition of students.

The general objectives of vocational training include:

- Development and improvement of necessary physical qualities;

- Acquisition of special movement skills and abilities in this profession;

- Increasing the level of physical development, physical fitness, resistance of the organism to the effects of adverse regional factors and strengthening health.

The special tasks formed taking into account the future professional activity of students include:

- Tasks aimed at ensuring a high level of physical development, functional state of the body and readiness for movement;

- Tasks aimed at the formation of professional skills and competencies required for further professional activity.

These tasks are solved on the basis of a scientifically based block system of organization of the educational process of professional and practical physical training of students, developed by us in the educational process.

The pedagogical monitoring carried out throughout the entire learning cycle includes an developed grading gradation. It helps to determine the general physical and special professional-practical physical training of students, to determine their rating of readiness for work and to find methods that help to motivate them to practical training in physical education and sports.

The scheme of the block-modular training system was used in the process of practical testing of the developed stage of professionalpractical physical training of students of the Faculty of Military Education before conscription. At the same time, taking into account the requirements for the Higher Courses of Sergeant Training of the Academy of the Ministry of Internal Affairs (AA Kochkarov, 2006) but the educational process in military specialties in higher humanitarian education institutions and the specifics of the future profession, we adopted the updated system $[5,6]$.

In this system, four modules were identified, each of which was divided into two blocks equal to one semester. The blocks focus on the development of general, special and vocational-practical physical training. The volume of physical loads in each training block, the tools used and the duration of their intended use were determined.

In the learning process, the modules are developed according to the scheme of jointconsistent organization of workload planning. Consistency here means the introduction of professional-practical physical training tools in a strict order and sequence. At the same time, the use of priority means of professional and practical physical training, taking into account the growing volume of workload, which has a positive effect on the body of students. Consistency in the use of professional physical training means has the necessary functional significance, on the basis of which the effect of the gradual increase in the volume and intensity of physical activity on the body of students is realized.

Classes are held in separate sections of physical training in order to develop professional and practical skills and gradually increase the level of general physical fitness of students. 
The method of complex training is carried out at the expense of physical exercises, which belong to the department, which is mastered in the classroom. Such exercises are performed at high intensity and last a long time, with rest periods that are optimal in terms of duration and effectiveness.

The use of such a complex of exercises causes great physical fatigue and helps to cope with the maximum physical stress, to combat the symptoms of fatigue [7].

According to $94 \%$ of professors and teachers who took part in the survey, the department of professional and practical physical training of students of the Faculty of Pre-Conscription Military Education is one of the leading disciplines, sports games (15.1\%), 61.3\% of students surveyed said that physical education should have a professional-practical orientation, and the amount of equipment should include martial arts (16.3\%), athletics (15.4\%) and sports (14.9\%). confessors [8].

In short, the formation of professional and pedagogical skills of a specialist in pre-service military education on the basis of modern requirements and new pedagogical experiences and technologies is one of the requirements of the time. In the process of teaching students, Professional Practical Physical Training serves as the main science department.

\section{REFERENCES}

1. Law of the Republic of Uzbekistan "On the National Training Program". Tashkent, August 29, 1997.
2. Azizxo'jaeva N.N. Pedagogical technology and pedagogical skills.- Tashkent, 2003.-174 p.

3. Gaiduk S.A. Technology of formation of volitional qualities in the process of PPFP: Monograph. I/ S.A. Gaiduk, L.V. Marshchuk.- MN. MGHRN. 2007 - 200 p.

4. Degtyarenko G.A. Fundamentals of modeling the process of forming the professional and applied qualities of officers in higher military educational institutions: Abstract of the thesis ... cand. Pedagogical Sciences, Moscow, 1990, 25 p.

5. Kochkarov A.A. PPPT (Professional practical physical training) of cadets of higher courses on training sergeants of the Academy of the Ministry of Internal Affairs of the Republic of Uzbekistan: Textbook. Publishing house "Academy of the Ministry of Internal Affairs of the Republic of Uzbekistan" Tashkent.: 2006 - 56 p.

6. Izaak V.M. PPPT (Professional practical physical training) in the system of physical education of students. Tutorial. Tashkent., 2003.-22 p.

7. Xankeldiev Sh.X., Khasanov A.T. Experimental substantiation of focused physical education classes of students of the Faculty of Pre-Conscription Military Education. //Fan-sport.- Tashkent., 2013. № 1.- 21-23p.

8. Khasanov A.T. Pedagogical technology of professionally applied physical training of students of faculties of pre-conscription military education. // Abstract of the thesis ... Doctor of Philosophy in Pedagogical Sciences. Chirchik. - 2018 .- 63 p. 